Developments in British Politics 3 
Also available from Macmillan Education

Peter Hall, Jack Hayward and Howard Machin (eds) DEVELOPMENTS IN FRENCH POLITICS

Gordon Smith, William E. Paterson and Peter H. Merkl (eds) DEVELOPMENTS IN WEST GERMAN POLITICS

Stephen White, Alex Pravda and Zvi Gitelman (eds) DEVELOPMENTS IN SOVIET POLITICS

\author{
Forthcoming \\ Patrick Dunleavy \\ ANALYSING BRITISH POLITICS
}

Gillian Peele, Christopher Bailey and Bruce Cain (eds)

DEVELOPMENTS IN AMERICAN POLITICS 


\title{
Developments in British Politics 3
}

\author{
Edited by \\ Patrick Dunleavy \\ Andrew Gamble \\ Gillian Peele
}

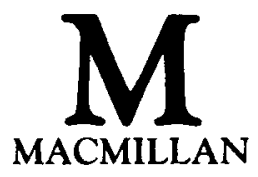

Publishers' note

This book is designed as a direct replacement

for Developments in British Politics 2 (see next page) 
Editorial matter and selection (C) Patrick Dunleavy, Andrew Gamble and Gillian Pcele 1990

Individual chapters (in order) (C) Patrick Dunleavy; Norman Barry; W. L. Miller; Gillian Pcele; Patrick Dunleavy; Gerard Stoker, Helen Wallace; Paul Whiteley; Albert Weale; Hugh Ward, David Samways and Ted Benton; Steve Smith; Brendan O'Leary; Cento Veljanovski; Geoff Whitty; Colin Crouch; Andrew Gamble 1990

All rights reserved. No reproduction, copy or transmission of this publication may be made without written permission.

No paragraph of this publication may be reproduced, copied or transmitted save with written permission or in accordance with the provisions of the Copyright, Designs and Patents Act 1988, or under the terms of any licence permitting limited copying issued by the Copyright Licensing Agency, 33-4 Alfred Place, London WCiE 7DP.

Any person who does any unauthorised act in relation to this publication may be liable to criminal prosecution and civil claims for damages.

First published 1990

This book replaces Developments in British Politics (first published 1983, reprinted 1983, revised edition 1984, reprinted with corrections 1985) and Developments in British Politics 2 (first published 1986, reprinted 1987, reprinted with corrections 1987, revised edition 1988, reprinted 1989)

Published by

MACMILI.AN EDUCATION I.TD

Houndmills, Basingstoke, Hampshire RG21 2XS

and London

Companies and representatives

throughout the world

Typeset by Footnote Graphics,

Warminster, Wilts

British Library Cataloguing in Publication Data

Devclopments in British politics 3.

1. Great Britain. Politics

I. Dunleavy, Patrick II. Gamble, Andrew III. Peele,

Gillian 1949-

320.941

ISBN 978-0-333-51368-2 ISBN 978-1-349-20795-4 (eBook)

DOI 10.1007/978-1-349-20795-4 


\section{Contents}

List of Contributors $\quad \mathrm{xi}$

Preface xiii

1 Introduction: Prospects for British Politics in the 1990s Patrick Dunleavy 1

The Ageing of the Government 2

Party Pendulum Effects 4

Development of the New Right Project 6

A New Public Agenda? 10

$\begin{array}{ll}\text { Conclusion } & 13\end{array}$

\section{Part One: The Political System}

2 Ideology Norman Barry 17

Cionsensus: An Ancien Régime? 19

Sources of Disharmony 20

Theoretical Origins of Thatcherism 21

'Marketing' the Market 22

Markets and Conservative Morality 24

The Attack on Social Justice 25

Questioning the Welfare State 26

Traditionalism, Modernism, and Thatcherism 28

A Retreat from Theory? $\quad 29$

Socialism in Crisis 31

Socialism and the Market $\quad 32$

Welfare and Citizenship $\quad 35$

Civil Liberties and the Constitution $\quad 36$

The Response of the 'Old' Left 37

Continued Conflict or a New Consensus? 37

3 Voting and the Electorate W. L. Miller 42

Sociological Model $\quad 46$ 
Party Identification Model $\quad 49$

Rational Choice Model 52

Dominant Ideology Model 55

Voting Contexts 61

The local election context $\quad 62$

The byelection context $\quad 63$

General elections $\quad 64$

The Euro-election context $\quad 65$

$\begin{array}{ll}\text { Conclusions } & 67\end{array}$

4 Parties, Pressure Groups and Parliament $\quad 69$

Gillian Peele

The Nature of the Party System $\quad 70$

The Conservatives in power $\quad 72$

The future of the Conservative leadership $\quad 74$

Conservative Party dissent $\quad 76$

Rebuilding the Labour Party $\quad 77$

Labour's image $\quad 78$

The policy review $\quad 79$

Black sections $\quad 80$

Constitutional reform $\quad 81$

Party organisation $\quad 82$

The Fragmentation of the Centre $\quad 84$

Scotland and the National Question $\quad 86$

Pressure Group Politics $\quad 88$

Parliament $\quad 91$

House of Lords $\quad 94$

Conclusion $\quad 94$

5 Government at the Centre 96

Patrick Dunleavy

Central Government and the Central State $\quad 97$

The Core Executive: PM and Cabinet 101

PM's personal predominance 102

Prime ministerial clique view 103

Cabinet government $\quad 105$

Ministerial government $\quad 106$

Segmented decisions $\quad 108$

Bureaucratic control models $\quad 110$ 
The Civil Service

The Intelligence Services $\quad 116$

Crises, Conflicts, and Policy-Making 121

Conclusions: Thatcherism and the Central State 124

6 Government Beyond Whitehall Gerry Stoker 126

The Main Agencies of Sub-Central Government $\quad 126$

Local authorities $\quad 127$

The National Health Service 129

National quasi-governmental agencies $\quad 129$

Local and regional QGAs $\quad 130$

Developments in Sub-Central Government 132

Restructuring local government 133

The reform of the NHS 138

Interpreting the Changes in Sub-Central Government 140

The centralisation thesis $\quad 140$

A matter of party advantage 143

A triumph of New Right ideology 144

$\begin{array}{ll}\text { Conclusion } & 147\end{array}$

7 Britain and Europe Helen Wallace 150

The European Political Context 151

British Adaptation to Europe in the Mid-1980s 157

The sovereignty issues 158

The European Community Changes Gear 159

A European agenda defined in London $\quad 160$

The institutional price of policy victory $\quad 161$

European Policies and British Interests 162

Conservative reservations $\quad 163$

Monetary dilemmas and British policy 165

The social dimension and party attitudes $\quad 166$

Shifting external policy interests $\quad 167$

The Implications for British Policy 168

The Impact on British Politics $\quad 170$

\section{Part Two: Public Policy}

8 Economic Policy Paul Whiteley 175

The Characteristics of Economic Policy-Making 176 
Macroeconomic Policy, 1979-89 179

Early monetarism $\quad 179$

Pragmatic monetarism $\quad 186$

'Reverse' monetarism $\quad 188$

After Lawson $\quad 191$

Macro-Effects on Microeconomic Policy, 1979-88 191

The Thatcher Experiment - Conclusions and

Prospects

9 Social Policy Albert Weale 197

The Programmes 200

The Politics of Income Maintenance 203

The 1985 Social Security review 205

Effects of the reform 208

The Politics of Health Gare 210

NHS expenditure 211

The NHS review 213

Opposition to NHS reforms 215

Other Dimensions of Welfare $\quad 217$

10 Environmental Politics and Policy 221

Hugh Ward with David Samways and Ted Benton

Environmental Politics $\quad 222$

The arrival of the Greens $\quad 222$

Environmentalism in other parties 224

How Environmental Policy is made 224

Energy and Electricity Privatisation 228

Transport $\quad 232$

Agriculture $\quad 234$

Water Pollution 237

European and International Dimensions 239

Conclusions 243

11 Foreign and Defence Policy Steve Smith 246

The Traditional Model 248

Constant features $\quad 249$

Changing features 251

External Influences on British Policy 253

Modernisation 253

Multilateralism 254 
Interdependence

The Contemporary Foreign Policy-Making Process 258

The Contemporary Defence Policy-Making

Environment

Current Problems

262

Conclusions

264

\section{Part Three: CurRent IsSues}

12 Northern Ireland and the Anglo-Irish Agreement Brendan O'Leary

The Content of the Agreement and its Rival Interpretations

Anglo-Irish Relations

273

The Political Process in Northern Ireland

Social Justice and Legal Justice

284

Fair employment

Legal justice

286

Violence and Security

288

Conclusion

13 The Political Economy of Regulation

291

Cento Veljanouski

What is Regulation?

292

Competing Models of Regulation

293

Nationalisation - Designed to Fail

The Evolution of Regulatory Policy

297

Privatisation

Liberalisation

299

European Community

300

The Proliferation of Watchdogs

301

The Techniques of Intervention

Prospects for the Future

14 The Politics of the 1988 Education Reform Act Geoff Whitty

The Great Education Reform Bill

Opposition to the Bill

Effects of the Education Reform Act

A New Politics of Education? 
x Contents

15 Industrial Relations Colin Crouch 318

Industrial Relations on the Ground 318

Government Intervention $\quad 322$

Tripartism 324

The Unions and Politics $\quad 325$

PART Four: Conclusion

16 The Thatcher Decade in Perspective

Andrew Gamble

Thatcherism

333

Interpretations of Thatcherism 334

Thatcherism as a political project $\quad 336$

Theories of British politics 338

Parliament and the Constitution $\quad 339$

Representative and responsible government $\quad 339$

The Westminster model $\quad 340$

Decline of representative government 341

Decline of responsible government 342

Rebuilding legitimacy $\quad 344$

Public Policy 346

The policy-making process $\quad 348$

Why government grows $\quad 348$

Rolling back the state $\quad 350$

Political Economy 351

Institutional sclerosis $\quad 352$

The developmental state $\quad 353$

Imperial overextension $\quad 354$

The unfinished revolution $\quad 354$

Decline or recovery? $\quad 355$

The End of Class Politics 356

Guide to Further Reading $\quad 359$

Bibliography $\quad 367$

Index $\quad 390$ 


\section{List of Contributors}

Norman Barry is Professor of Politics at the University of Buckingham. Recent publications include Hayek's Social and Economic Philosophy; The New Right; and Welfare.

Ted Benton is Senior Lecturer in Sociology at the University of Essex, and is researching on social theory and environmental issues.

Colin Crouch is Fellow and Tutor in Politics at Trinity College, Oxford. Recent publications include The Politics of Industrial Relations; and Trade Unions: The Logic of Collective Action.

Patrick Dunleavy is Professor of Government at the London School of Economics and Political Science. Recent publications include Theories of the State: The Politics of Liberal Democracy (co-author); and Democracy, Bureaucracy and Public Choice.

Andrew Gamble is Professor of Politics at the University of Sheffield. Recent publications include Britain in Decline (third edition); The Free Economy and the Strong State; and Thatcher's Law (co-editor).

William L. Miller is Professor of Politics at the University of Glasgow. Recent publications include Irrelevant Elections? The Quality of Local Democracy in Britain; and How Voters Change: The 1987 Election Campaign in Perspective (co-author).

Brendan O'Leary is Lecturer in Public Administration at the London School of Economics and Political Science. Recent publications include The Asiatic Mode of Production; Theories of the State: The Politics of Liberal Democracy (coauthor); and The Future of Northern Ireland (co-editor).

Gillian Peele is Fellow and Tutor in Politics at Lady Margaret Hall, Oxford. Recent publications include British Party Politics: Competing for Power in the 1990s; The Government of the United Kingdom: Political Authority in a 
Changing Society (second edition) (co-author); and Developments in American Politics (co-editor).

David Samways is a graduate student in the Department of Government at the University of Essex, and is researching on the politics of the ozone layer.

Steve Smith is Senior Lecturer in International Relations and Director of the Centre for Public Choice Studies, University of East Anglia. Recent publications include British Foreign Policy (co-editor); and Explaining and Understanding International Relations (co-author).

Gerry Stoker is Lecturer in Government at the University of Essex. Recent publications include The Politics of Local Government; and The Future of Local Government (co-editor).

Cento Veljanovski is Research and Editorial Director at the Institute of Economic Affairs. Recent publications include Selling the State; and Law and Economics.

Helen Wallace is Director of the West European Programme at the Royal Institute of International Affairs, Chatham House. Recent publications include Europe: The Challenge of Diversity; and Policy-Making in the European Community (co-editor).

Hugh Ward is Lecturer in Government at the University of Essex. Recent publications include 'Environmental Groups' in D. Marsh (ed.), Pressure Politics; and 'Neutrality of Sciences and Technology', in A. Reeve and B. Goodin (eds), Liberal Neutrality.

Albert Weale is Professor of Politics at the University of East Anglia. Recent publications include Political Theory and Social Policy and a number of papers relating political ideas to public policy.

Paul Whiteley is the Pamela V. Harriman Professor of Government and Public Policy at the College of William and Mary, Virginia. Recent publications include The Labour Party in Crisis; and Political Control of the Macroeconomy.

Geoff Whitty is Goldsmiths' Professor of Policy and Management in Education in the University of London. Recent publications include Sociology and School Knowledge; and The State and Private Education (co-author). 


\section{Preface}

This is the third Developments in British Politics volume. Like its predecessors, it aims to provide a rigorous analysis of contemporary events and recent changes in the British political scene. As with previous volumes, all the chapters included here are wholly new and, with the exception of the editors, a completely different set of authors has been recruited for this project. These authors represent a range of viewpoints and, while all have been asked to combine sensitivity to theoretical issues with their discussion of empirical issues, there has been no attempt to impose uniformity on the treatment of individual themes.

Readers familiar with the format of Developments in British Politics will notice that we have made a number of substantial changes in this volume. Firstly, the interpretative overview written by Patrick Dunleavy with which previous volumes concluded has now been removed and extended into a separate book, Analysing British Politics (Dunleavy, forthcoming). Because analytic themes and debates change more slowly than political processes themselves, there seemed little justification for reprinting essentially similar material in each new volume of Developments in British Politics especially given the frequency with which we revise and update our material. Instead, we have included in this edition a short introduction which considers some of the major avenues for change in the British political scene open in the 1990s and a concluding chapter which looks at some overarching themes raised by the detailed topic chapters. We hope that this rearrangement of the book, which brings it into line with the companion volumes on German, French, Soviet and American politics which have grown out of our original conception, will make it more accessible and useful for students and teachers.

Secondly, we have given more prominence to the European dimension of British politics. A new Part One chapter focuses 
on Britain's relations with the European Community. But in addition we asked all our contributors to consider the ways in which British involvement in the European Community has affected their subject area. In most cases substantial new sections of individual chapters have resulted and in all chapters this previously somewhat hidden topic is now explicitly considered. Our focus is still firmly on British politics, but the politics of a Britain increasingly integrated with its European neighbours rather than the freestanding polity beloved of many traditional textbooks.

Thirdly, we have been able to expand our coverage of empirical changes into new areas. Most notably we have responded to the rapid growth of environmental issues and politics by including a new Part Two policy chapter to complement those on social, economic and foreign policy which have appeared in previous editions. In our judgement, increased environmental awareness and the politicisation of 'green' issues is likely to be a permanent feature of the British political scene in the 1990s.

Fourthly, our selection of current issues for coverage in Part Three includes chapters on education (where the government's reforms have been particularly extensive) and the nexus of issues surrounding privatisation and deregulation.

Any contributed volume depends to a large extent for its success on the cooperation of individual authors and their willingness to submit to deadlines and requests for last-minute revisions and changes. We have been fortunate once again in our team. Despite heavy teaching and writing commitments and in some cases the complications of extensive travel, all our authors kept their part of the collective academic bargain.

A special acknowledgement is due to Henry Drucker who left the editorial team after his appointment as Director of Development at the University of Oxford. Henry conceived the idea of Developments in British Politics, and was general editor for the first two volumes. We greatly missed his editorial skills this time, and for our part and on behalf of the publishers would like to record our thanks for all he has contributed. We should also like to thank Bruno Bargery, John Barnes, Brendan O'Leary, and Seamus Tucker, all of whom gave special assistance with the production of the book. 
As in previous volumes we owe a heavy debt to our publisher Steven Kennedy without whose intellectual input and practical advice the project would be much the poorer.

Finally we thank the many students, teachers, academics, and general readers who have pointed out neglected issues or topics not explored in Developments in British Politics 2. We are keen to have as much feedback as possible, and welcome comments on this edition, and suggestions for the future.

Patrick Dunleavy, Dept. of Government, LSE, Houghton St., London WC2A 2AE

Andrew Gamble, Dept. of Politics, University of Sheffield, Sheffield S10 2TN

Gillian Peele, Lady Margaret Hall, Oxford OX2 6QA 